\title{
The Impact of Serious Games in Economic and Business Education: A Case of ERP Business Simulation
}

\author{
Tina Beranič *(D) and Marjan Heričko (D)
}

check for updates

Citation: Beranič, T.; Heričko, M. The Impact of Serious Games in

Economic and Business Education: A

Case of ERP Business Simulation.

Sustainability 2022, 14, 683. https:// doi.org/10.3390/su14020683

Academic Editor: Wadim

Strielkowski

Received: 15 November 2021

Accepted: 4 January 2022

Published: 8 January 2022

Publisher's Note: MDPI stays neutral with regard to jurisdictional claims in published maps and institutional affiliations.

Copyright: (C) 2022 by the authors. Licensee MDPI, Basel, Switzerland. This article is an open access article distributed under the terms and conditions of the Creative Commons Attribution (CC BY) license (https:// creativecommons.org/licenses/by/ $4.0 /)$.
Faculty of Electrical Engineering and Computer Science, University of Maribor, Koroška cesta 46, 2000 Maribor, Slovenia; marjan.hericko@um.si

* Correspondence: tina.beranic@um.si

\begin{abstract}
Digitalisation nowadays impacts business environments significantly. Therefore, if higher education wants to educate students properly for a successful career path, the business and economics curriculum must be enriched with innovative teaching approaches covering actual topics, such as, for example, the implementation of the ERPsim business simulation, a representative of serious games. The ERPsim business simulation is based on SAP ERP, and is aimed at teaching ERP concepts. It covers different business processes, and allows students to learn using a hands-on approach, simulating real-life scenarios. The presented research focuses on using an ERPsim business simulation as the introduction to the course. The simulation was implemented to ease the introduction of ERP and IT concepts to the business and economic oriented students. Considering the positive effects of serious games and gamification, our research was formed and focused on knowledge acquisition and future student engagement. We researched whether participation in the introductory simulation results in significant knowledge gain and impacts students' future course engagement. The data were gathered using a self-assessment questionnaire before and after an introductory simulation. The results were highly positive, confirming many positive aspects of business simulation, among others, significant knowledge increase in the domains of business process and ERP transactions, and in the domain of technical knowledge for SAP ERP. The results confirmed that the introductory simulation is appropriate for introducing ERP concepts to newcomers, and, nevertheless, confirmed the positive impact on their intent on future course engagement.
\end{abstract}

Keywords: business simulation; knowledge acquisition; course engagement; ERPsim; SAP; gamification

\section{Introduction}

Digital transformation is increasingly important in many areas, including education. Nowadays, students are being educated and prepared to work successfully in highly digital environments. Therefore, the strong involvement of advanced information and communication technology (ICT) represents an important and necessary part of education. This is especially true for higher education, which represents the final step before employment. Even though the use of technology in teaching is already an established procedure [1,2], the current situation requires even closer interweaving with ICT, regardless of the course, supporting sustainable study programs. Hence, the business and economic education is no exception. Digitalisation has already impacted strongly and transformed the abovementioned domain significantly. Consequently, the reflection of digitalisation topics in the current business and economics curriculum is a highly important topic.

Nowadays, the use of ICT in business environments, even within small and mediumsized enterprises, is essential. In addition to essential digitalisation tools, many companies also use advanced and complex ICT tools, such as, for example, enterprise resource planning (ERP) solutions. Since the ERP systems significantly influence the organisations' performance, the use is inevitable to remain competitive [3]. Therefore, it is important that students become familiar and use those tools practically already during their studies, if 
possible even in the form of real-life scenarios. This can be achieved with the use of simulation games, namely, business simulation games. Business simulations play an essential role nowadays in study programmes, since engaging in simulations enables the sustainable knowledge transfer between education and industry [4]. One of the representatives is the ERPsim business simulation [5] based on SAP ERP. It covers different business scenarios, and simulates a real business environment in which students have to make business decisions according to gathered data and collaboration between the various business roles in the company. This allows a holistic view of the business environment, which is highly desirable by the global business community [6].

The use of serious games in education is an evolving topic, receiving a lot of research interest. Unlike traditional entertainment games, serious games are designed and used to fulfil learning objectives, therefore, for educational purposes [2,7-9]. Serious games are a form of gamification, incorporating traditional gaming elements into learning [8]. As full-featured games [10], serious games are intended for education and different serious purposes, like industry training and simulation [8,11-13]. According to a review provided by Connolly et al. [13], the majority of serious games are simulations.

The use of serious games in the educational process has many advantages, which can be aligned with the positive effects of gamification. The main development goals of serious games are learning and behaviour change [13]. Serious games can motivate learners [14] and provide the environment for practice [14]. Positive findings were also detected by Zhonggen [2], who reviewed the available literature systematically in order to explore the effectiveness of serious games in education. As stated, serious games can facilitate the holistic understanding of the specific topic, enhance cognitive abilities, improve academic achievements in the form of learning outcomes, provide flexible learning and other advantages [2]. According to Krath et al. [11], researchers, when looking into gamification or serious games outcomes, among others, focus on behavioural, learning and motivational outcomes. Within learning outcomes, the researchers report about an improvement of critical and creative thinking, knowledge acquisition, content understanding and perceptual skills $[11,13,15-18]$.

Given the many positive aspects of gamification and serious games, its widespread use can also be detected in higher education [17,19-21]. Innovative teaching approaches are becoming increasingly important, since they can address current educational challenges successfully. Therefore, the use of serious games can be detected in different economics and business education fields. Serious games are used in management education and training [8,22], accounting education [23] and also entrepreneurship education [24]. According to the review implemented by Boyle et al. [25], which updated the review by Connolly et al. [13], the majority of games for business and economics are simulations. The use of serious games within the educational process varies [2]. Based on the goal that we want to achieve, they can present the major focus of the course, or can be used just as a supplement to traditional learning approaches, i.e., lectures and lab works. Additionally, they can be used throughout the whole course, or just at the beginning of the course.

The presented research focuses on a case study of ERPsim business simulation implemented within a very first course session in a business oriented study programme. We used the simulation as an introduction to the course, in order to ease the introduction of ERP and IT concepts to business and economics students obtaining a professional degree. By following highly positive outcomes and feedback of our previous research [26], we decided to research whether a similar approach can be beneficial and suitable also in non-IT study areas, as in current research, in the business oriented study programme.

Within the research, we focused on two main domains, knowledge acquisition and future student engagement. Since the related work points out improved learning outcomes as one of the benefits of the serious game implementation, we researched whether there is a significant knowledge increase within three learning outcome domains. Two of them are business oriented, namely business knowledge and ERP transactions knowledge, while one is 
IT oriented, namely technical knowledge for SAP ERP. Therefore, our research is focused on the following research questions:

RQ 1 Does an ERPsim introductory session improve the students' knowledge in the business process knowledge domain?

RQ 2 Does an ERPsim introductory session improve the students' knowledge in the domain of technical knowledge for SAP ERP?

RQ 3 Does an ERPsim introductory session improve the students' knowledge in the ERP transaction knowledge domain?

In addition to the main research questions, we also looked into how the business simulation affects students' overall motivation, strategy and communication.

The second part of the research focused on the perceived impact of business simulation on students' future course engagement since the achievement of an active engagement is an increasing challenge within higher education. The research followed the following research question:

RQ 4 Does an ERPsim introductory session affect students' intent for future course engagement?

The paper is organised as follows. Section 2 presents the theoretical background and related work, focusing on serious games, the ERPsim business simulation and its use in the educational process. The following section presents the methodology of the presented research, covering the implementation of the ERPsim business simulation, presenting the demographic data, research model and data collection. Section 4 presents the results and discussion, offering the answer to the formed research questions. The section is divided into two subsections, first, discussing perceived knowledge acquisition, and second, focusing on teams' strategy, motivation and students' future course engagement. The paper ends in Section 6, presenting a conclusion and future research.

\section{Theoretical Background and Related Work}

\subsection{Serious Games}

The naming of serious games had been detected widely after the year 2002, although games aimed at serious purposes were already in use before this year [27]. The first differentiation between entertainment games and games for learning was made by Abt [28], who defined the game as "an activity among two or more independent decision-makers seeking to achieve their objective in some limiting context" [28], wherein the main goal in the serious games is learning [8,28]. According to Abt [28], two main components of the games can be distinguished, rational or analytic ones and emotional or creative ones. In his book, Abt [28] used the naming of serious games with a meaning closely related to the present understanding of serious games. Djaouti et al. [27] present a history of serious games, dating back to 1951 . As mentioned, early video games aimed at training the professionals were already available in 1955 in the military domain [27]. Additionally, the ancestors of serious games can be detected in the education domain already in the 1970s, and in corporate training and advertising in the 1970s and 1980s [27]. According to the research provided by Djaouti et al. [27], the majority of serious games before 2002 were available in the educational domain, namely $65.8 \%$, while this percentage decreased significantly after 2002 , and only $25.7 \%$ of serious games can be categorised into the educational domain.

Serious games represent just one of the gamification learning methods $[8,29]$. Therefore, the difference between gamification and serious games has to be respected. According to Sanmugam et al. [30] serious games involve the usage of the whole system of gaming, while gamification uses just some part of the game elements. Additionally, gamification does not always involve the game environment [31]. Among serious games, simulations present the most common game genre [13,25]. According to Boyle et al. [25] simulations aid learning by providing virtual activities that reflect the real word activities. Simulations were first used within aeronautics and military training. However, from the 1950s, they can also be detected within business and economics education [32]. From then on, the 
domain evolved rapidly. Nowadays, one of the visible representatives of serious games and simulations in the business and economics domain is ERPsim [5], the business simulation used in the presented research.

\subsection{The Use of the ERPsim Business Simulation in Education}

Business simulation enables players to operate in the virtual environment for training purposes [33]. According to Greco et al. [34], business games are very popular within management education, and, as summarised by Ferreira et al. [35], business simulation games present an example of e-learning methodology in business education. As mentioned, one of the well established representatives of business simulation games is the ERPsim simulation [5] aimed at teaching ERP concepts. The simulation was presented in 2006 in an article by Léger [36]. The ERPsim simulation was developed to ease the understanding of complex and challenging thematic connected to ERP systems [36,37], and can help students in gaining missing business and IT knowledge [36].

The ERPsim simulation is used widely in higher education [38]. While the majority of studies focus on enhancing students' knowledge, for example, Chen et al. [39], Darban et al. [40] and Seethamraju [41], some studies focus on different research topics, like Geoffrey and Asli [42], who explored whether ERPsim simulations can be used in the education of other management disciplines and Zhao et al. [43], who researched the perceived team cohesion influence on their perception of flow experience. The ERPsim simulation was also the subject of our previous research [26], where we used an ERPsim simulation as an introduction to the ERP Systems course. The paper focused on teaching the ERP concepts to IT-oriented students, who differ significantly from the population of our current research. Unlike the present research, students had much more IT-oriented knowledge, wherein, in the current study, the participants are from the not-IT degree programme. Since the results of the three-year research confirmed very positive experiences and perceived a positive impact on students' knowledge and engagement, we decided to broaden our research to the economics and business degree students. In comparison to related work, our study focuses on researching the positive aspects of using a business simulation as an introduction to a course, wherein the traditional teaching approaches are implemented in the continuation of the course. Since the implementation of business simulation through a whole semester requires many resources and effort, the presented approach offers an intermediate path. A quick course adaptation results only in minor changes and limited resources needed since only a limited number of hours are intended for the business simulation. In the continuation, we also present the outline of the implemented introductory workshop, which can be used as a basis for interested parties.

\section{Methodology}

\subsection{Implementation of the ERPsim Business Simulation and Demographic Data}

Since its introduction [36] the ERPsim simulation has evolved constantly. ERPsim [5] now supports nine simulation scenarios combined into four groups: (1) Distribution, (2) Logistics, (3) Manufacturing, and (4) Retail Game. Within each simulation, scenarios enable a gradual complexity increase. For example, the Manufacturing Game supports three different scenarios, Introduction, Extended and Advanced Scenarios. Within the Manufacturing Introduction simulation, participants use the basic set of transactions. In the Extended scenario, four additional transactions are added, and in the Advanced scenario, participants have to deal with an additional business domain, resulting in an even more detailed simulation. The Manufacturing Advanced simulation scenario is the most complex ERPsim simulation, covering the most comprehensive scope of ERP transactions. On the other hand, the ERPsim Distribution Game presents the introductory simulation covering the basic ERP functionalities. This simulation is aimed at performing a business cycle through planning, procurement and selling.

Within the presented research, the ERPsim Distribution simulation was used, since we used the simulation as the introduction to the course. In the chosen simulation, participants 
operate in a distribution company that sells bottled water to Convenience Stores in a German market. The company operates with six different products, ClearPure, Spritz and Lemon Spritz water in two different sizes, $1 \mathrm{~L}$ and $500 \mathrm{~mL}$. The market is divided into three regions, wherein each region has unique purchasing preferences [44,45].

At the beginning of the simulation, the participants are introduced to JobAid, twopages of instructions. One page covers the information about the company, its products, and market. On the other page, participants are introduced to the ERP transactions that they have to implement during the simulation. Participants are using an SAP ERP system in the same form as in real-life industrial environments. However, some of the transactions are automated, to allow the participants to focus on more creative, decision-based transactions. Table 1 depicts transactions that are supported within the ERPsim Distribution simulation. The table presents a business process, corresponding transactions and transaction codes that can be used within SAP ERP.

Table 1. ERP transactions within the ERPsim Distribution simulation.

\begin{tabular}{lll}
\hline Business Process & Transaction & Transaction Code \\
\hline \multirow{2}{*}{ Sales Process } & Change Price & VK32 \\
& Marketing Expense Planning & ZADS \\
\hline Procurement Process & Create Purchase Orders & ME59N \\
\hline \multirow{2}{*}{ Planning Process } & MRP Run & MD01 \\
& Create Planned Independent Requirements & MD61 \\
& Summary Sales Report & ZVC2 \\
& Detailed Sales Report & ZVA05 \\
& Price Market Report & ZMARKET \\
& Purchase Order Tracking & ZME2N \\
& Procurement Sourcing & ZME13 \\
& Inventory Report & ZMB52 \\
& Financial Statements & F.01 \\
\hline
\end{tabular}

The simulation is implemented in three sequential rounds. In the first round, participants perform the transactions within the Sales Process, changing the prices of their products within the selling regions and investing in marketing activities. The marketing can be done for each product in each German region. In the first round, the participants can check the Inventory Report to track their stocks, and look into the sales and price reports, which can help them design and adjust the company's selling strategy. For example, the Price Market Report shows market sales data and is available every five days. In the second round, the participants need to restock their inventories. They can use the MRP Run and Create Planned Independent Requirements transactions in order to convert Purchase Requisitions into Purchase Orders. It is essential that they track their Purchase Orders, and also monitor other available reports continuously. In the third round, the participants implement the whole business cycle, completing the planning process with the Create Planned Independent Requirements Transaction [45].

The outline of the ERPsim introductory session, as implemented within the presented research, can be seen in Figure 1. 


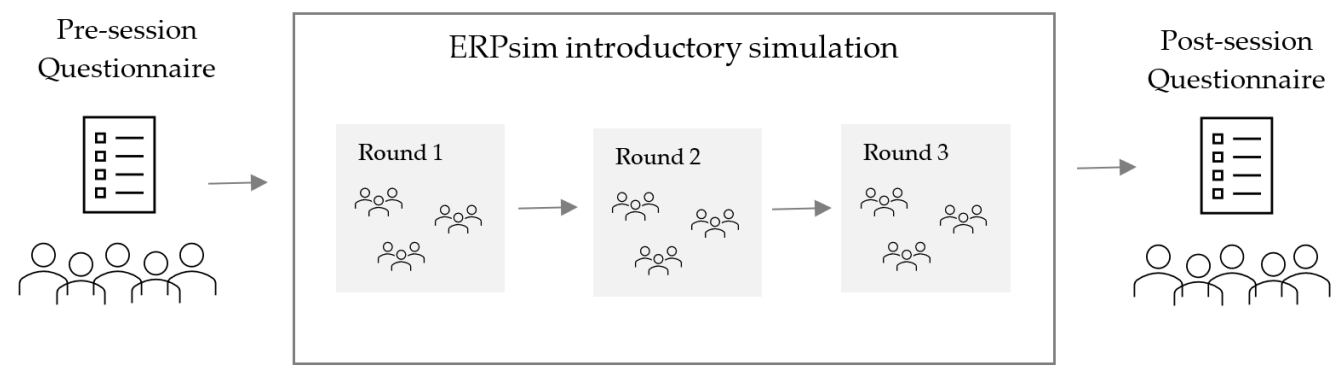

Figure 1. Outline of the performed research and implemented ERPsim business simulation introductory simulation.

The students were combined into groups of three or four participants, which were formed according to their own wishes. Before each round, they were given the time for forming the strategy, while, after every round, we performed a debriefing in which the results of the simulation were shown to the participants, and they were encouraged to share their experiences and thoughts with others groups. It has to be mentioned that the introductory session was implemented with the goal of easing the introduction into the course, wherein the course was continued with the use of traditional teaching approaches. Additionally, the participants were not graded based on the results that their companies achieved during the session. Because of this, they have the ability to experiment freely and focus on gaining new knowledge, which is also one of the important good practices when using simulation within the course [46].

\subsection{Research Model and Data Collection}

A survey was implemented in order to answer the formed research questions, presented in Section 1. Surveys are appropriate for gathering self-reported beliefs and opinions from participants [47]. The participants were asked to answer online pre- and post-session questionnaires, as depicted in Figure 1. The survey was performed anonymously, using only an ERPsim user name, which was not connected to students' real identities. This was done with the aim to objectify the data as much as possible.

The sample of the survey presented 32 students who were involved actively in an ERPsim introductory simulation. The average age was 21.59 years, with a standard deviation of 1073 , and a minimum value of 20 and a maximum value of 24 . There were seven male and 25 female participants. The survey was performed in the business and economic professional higher education programme before and after the ERPsim introduction session. The duration of the study programme is three years, and the students can choose between different fields of business and economics thematic education.

According to their answers, the participating students are highly involved in their study process. With the high average value of 4.53 on the scale from 1 to 5 and a standard deviation of 0.671 , they expressed their agreement with the statement that they attend most of the lectures in their study. With a similarly high result, the average value of 4.50 and standard deviation 0.622 , the students agreed with the statement that they perform their study assignments regularly. Overall, $56.3 \%$ of the students did not have any experience with ERP solutions, and they were complete newcomers. Additionally, none of the participants were experienced ERP users, while $40.6 \%$ of the students assessed their experiences with ERP solutions with 2 or 3 on a scale from 1 to 5 . We also asked the participants to self-assess their IT knowledge using the 5-point scale, where 1 stands for very low and 5 stands for excellent. On average, the students assessed their knowledge with 3.22 with a standard deviation of 0.751 .

The questionnaires were formed according to the research model and following the best practices presented by Neuman [47]. The research model, shaped on the basis of the stated research questions presented in Section 1, is depicted in Figure 2.

The pre-session questionnaire was developed with the goal of gathering the: 
- Demographic data,

- Study process involvement data,

- Experience data, and

- Knowledge self-assessment data before the session.

With the post-session questionnaire, we gathered the following:

- Knowledge self-assessment data,

- Data about gained business and technical knowledge and skills,

- Data about simulation motivation and the used strategy,

- Data about team communication and role and task division,

- Data about gamification, serious games and simulation, and

- Data about future course engagement.

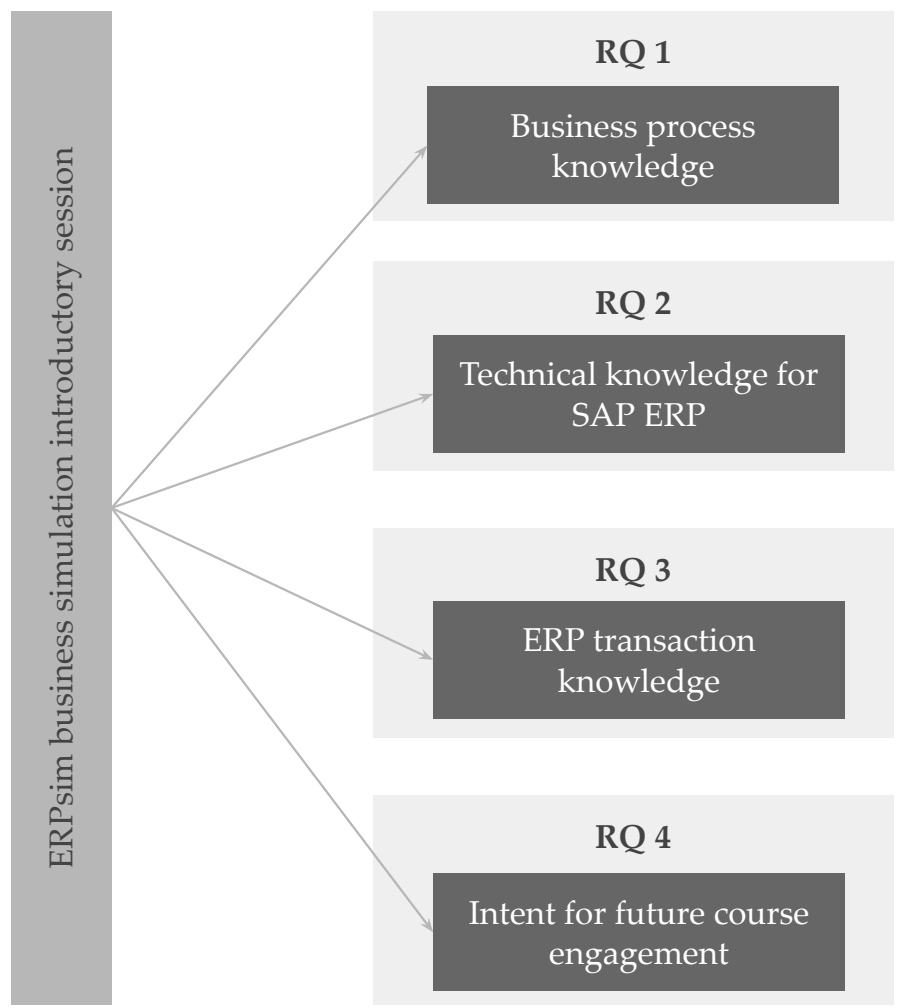

Figure 2. Research model focusing on the implemented ERPsim introductory session.

Within the questionnaires, participants' opinions and experiences were gathered using a self-assessment statement and a 5-point scale. According to Cronan et al. [48], who compared the learning outcomes in the ERP business simulation domain, there exists a significant correlation between self-assessed knowledge and the use of objective measures [48]. Therefore, the use of self-assessment scales for assessing students' knowledge and skills is suitable. After the data were gathered, the analysis was done using an SPSS statistics tool [49]. The analysis was done according to different thematic domains, providing answers to the formed research questions and some additional information. The results are presented hereinafter in Section 4 and its Subsections.

\section{Results and Discussion}

\subsection{Perceived Knowledge Acquisition}

The main goals of the presented research was to research whether the ERPsim introductory simulation session effected participant knowledge positively in three different knowledge domains:

\section{- Business process,}


- Technical knowledge for using SAP ERP, and

- ERP transactions.

As shown in the research model in Figure 2, knowledge acquisition is covered with $\mathrm{RQ} 1, \mathrm{RQ} 2$ and RQ3. Three hypotheses were developed, according to the formed research questions:

Hypothesis H1 There is a significant difference in the students' business process knowledge before and after the ERPsim introductory simulation.

Hypothesis $\mathbf{H} 2$ There is a significant difference in the students' technical knowledge for SAP ERP before and after the ERPsim introductory simulation.

Hypothesis H3 There is a significant difference in the students' ERP transaction knowledge before and after the ERPsim introductory simulation.

With the pre-questionnaire, used before the introductory session, the students selfassessed their knowledge in the mentioned domain before participating actively in the ERPsim business simulation. The same knowledge domains were again re-self-assessed by the students within the post-questionnaire. This time, after the ERPsim introductory session, in order to check whether the ERPsim simulation had had a positive impact on their knowledge acquisition. The gathered values are presented in Tables 2 and 3.

Table 2. Average team knowledge in different knowledge domains before and after the ERPsim business simulation introductory simulation.

\begin{tabular}{|c|c|c|c|c|c|c|c|c|c|}
\hline & $\begin{array}{c}\text { Team } \\
\# 1\end{array}$ & $\begin{array}{c}\text { Team } \\
\# 2\end{array}$ & $\begin{array}{c}\text { Team } \\
\text { \# } 3\end{array}$ & $\begin{array}{c}\text { Team } \\
\text { \# } 4\end{array}$ & $\begin{array}{c}\text { Team } \\
\text { \# } 5\end{array}$ & $\begin{array}{c}\text { Team } \\
\text { \# } 6\end{array}$ & $\begin{array}{c}\text { Team } \\
\text { \# } 7\end{array}$ & $\begin{array}{c}\text { Team } \\
\text { \# } 8\end{array}$ & $\begin{array}{c}\text { Team } \\
\# 9\end{array}$ \\
\hline Business process knowledge & 2.50 & 2.57 & 2.75 & 2.50 & 2.75 & 3.00 & 3.33 & 3.67 & 2.33 \\
\hline Technical knowledge for SAP ERP & 2.25 & 1.25 & 1.75 & 1.75 & 1.75 & 1.67 & 2.00 & 2.00 & 1.33 \\
\hline \multirow[t]{3}{*}{ ERP transaction knowledge } & 2.00 & 1.25 & 1.50 & 1.50 & 2.00 & 1.33 & 2.00 & 1.33 & 1.33 \\
\hline & $\downarrow$ & $\downarrow$ & $\downarrow$ & $\downarrow$ & $\downarrow$ & $\downarrow$ & $\downarrow$ & $\downarrow$ & $\downarrow$ \\
\hline & $\begin{array}{c}\text { Team } \\
\text { \# } 1\end{array}$ & $\begin{array}{c}\text { Team } \\
\text { \#2 }\end{array}$ & $\begin{array}{c}\text { Team } \\
\text { \# } 3\end{array}$ & $\begin{array}{c}\text { Team } \\
\text { \# } 4\end{array}$ & $\begin{array}{c}\text { Team } \\
\text { \# } 5\end{array}$ & $\begin{array}{c}\text { Team } \\
\text { \# } 6\end{array}$ & $\begin{array}{c}\text { Team } \\
\text { \# } 7\end{array}$ & $\begin{array}{c}\text { Team } \\
\text { \# } 8\end{array}$ & $\begin{array}{c}\text { Team } \\
\# 9\end{array}$ \\
\hline Business process knowledge & 4.00 & 4.00 & 3.75 & 3.25 & 3.25 & 3.33 & 3.33 & 3.67 & 3.67 \\
\hline Technical knowledge for SAP ERP & 4.00 & 3.50 & 3.75 & 3.50 & 3.00 & 2.67 & 3.33 & 3.33 & 3.67 \\
\hline ERP transaction knowledge & 3.75 & 3.75 & 4.00 & 3.25 & 3.00 & 3.33 & 3.33 & 3.00 & 3.67 \\
\hline
\end{tabular}

Table 2 presents the differences in the average values of each knowledge domain selfassessed by the students before the ERPsim introductory simulation. Three or four students formed the teams, wherein the students were allowed to form the groups according to their own wishes. The students assessed their knowledge using a 5-point scale, where 1 stands for very low and 5 stands for excellent. As seen, the average values between the groups vary. For example, in the domain of business process knowledge, the lowest value is 2.33 and the highest 3.67. On the other hand, in the knowledge domain with the lowest average value, ERP transaction knowledge, the lowest value is 1.25 and the highest 2.00.

The average values for the whole participating sample are presented in Table 3 . The Table presents the average knowledge assessment for the three knowledge domains covered in the research questions. The domain of business process knowledge was rated the highest before and after the simulation. The average value before the simulation was 2.81 , while the value after the simulation was 3.59. The highly assessed knowledge of the business process knowledge domain is not surprising, since the participant students are studying business and economics topics. Therefore, a lot of knowledge has already been received in other subjects. The students rated their technical knowledge for using SAP ERP with an average value of 1.75 before and 3.44 after the ERPsim simulation. The knowledge domain 
that was assessed with the lowest value before the introductory session was knowledge of ERP transactions. On average, their students self-assessed their knowledge with 1.59 before and 4.37 after the introductory simulation. This was also the domain with the highest knowledge increase. On average, the knowledge was increased by 1.88 .

Table 3. Average value and standard deviation of assessed knowledge in different knowledge domains before and after the ERPsim business simulation introductory simulation.

\begin{tabular}{lccccc}
\hline & \multicolumn{2}{c}{ Before ERPsim } & \multicolumn{3}{c}{ After ERPsim } \\
Knowledge Domain & Mean & SD & $\boldsymbol{\Delta}$ & Mean & SD \\
\hline Business process knowledge & 2.81 & 0.78 & $\nearrow 0.78$ & 3.59 & 0.56 \\
Technical knowledge for SAP ERP & 1.75 & 0.67 & $\nearrow 1.69$ & 3.44 & 0.56 \\
ERP transaction knowledge & 1.59 & 0.67 & $\nearrow 1.88$ & 3.47 & 0.57 \\
\hline
\end{tabular}

In order to test the hypotheses $\mathrm{H} 1, \mathrm{H} 2$ and $\mathrm{H} 3$, which looked for a significant knowledge increase in three knowledge domains, business process knowledge, technical knowledge for using SAP ERP and ERP transactions knowledge, we had to implement the additional analysis. In the first step, we checked the distribution of the variables with the use of the Kolmogorov-Smirnov normality test. All the six variables measuring selfassessed students' knowledge in three knowledge domains before and after the ERPsim introductory simulation were tested for normality. The null hypothesis was rejected with the significance $<0.001$. Therefore, all six variables are not distributed normally. There is a statistically significant difference between variable values and the normal distribution.

According to the data distribution, the Related-Samples Wilcoxon Signed Rank Test was used to research the stated hypotheses. The results are presented in Table 4. According to the results of the tests, it can be observed that there was a significant difference between pre- and post-session assessments for all of the three knowledge domains. Consequently, we can conclude that there was a significant difference in the students business process knowledge, technical knowledge for SAP ERP and ERP transaction knowledge before and after the ERPsim introductory simulation. Therefore, the hypotheses are confirmed.

Table 4. The results of the hypothesis testing with the Related-Samples Wilcoxon Signed Rank Test.

\begin{tabular}{llcc}
\hline Hypothesis & Knowledge Domain & Z & Sig. \\
\hline H1 & Business process knowledge & -3.843 & $<0.001$ \\
H2 & Technical knowledge for SAP ERP & -4.711 & $<0.001$ \\
H3 & ERP transaction knowledge & -4.769 & $<0.001$ \\
\hline
\end{tabular}

The students were also asked to assess some additional statements researching the impact of the ERPsim introductory simulation on gained business and technical knowledge and skills. The assessments were again done on a scale from 1 to 5 , with 1 standing for strongly disagree and 5 standing for strongly agree.

With an average score of 4.44 and a standard deviation of 0.564 , students agreed that they gained new business knowledge and skills during the ERPsim business simulation. Additionally, they agreed that they gained new technical knowledge and skills for using SAP ERP. This was evident from an average score of 4.31 and a standard deviation of 0.535 . Some additional statements connected to business and technical knowledge and skills are presented in Table 5. With an average score between 4 and 5, the students confirmed all of the statements. All of them agreed, or even strongly agreed, with the statement that ERPsim contributes to understanding basic business management concepts, and that ERPsim contributes to understanding the need for collaboration in the organisation. On the other hand, all of them also agreed, or strongly agreed, that the ERPsim simulation contributes to developing the technical skills necessary for the use of SAP ERP. Some other results are presented in Table 5 . 
Table 5. The impact of the ERPsim introductory simulation on students' business and technical knowledge and skills.

\begin{tabular}{|c|c|c|c|c|c|c|c|}
\hline $\begin{array}{l}\text { The impact of ERPsim on business } \\
\text { knowledge and skills }\end{array}$ & 5 & 4 & 3 & 2 & 1 & Mean & SD \\
\hline $\begin{array}{l}\text { Contributes to the understanding of basic } \\
\text { business management concepts. }\end{array}$ & $56.3 \%$ & $43.8 \%$ & $0 \%$ & $0 \%$ & $0 \%$ & 4.44 & 0.504 \\
\hline $\begin{array}{l}\text { Contributes to the understanding of the } \\
\text { interaction between the individual business } \\
\text { functions and processes. }\end{array}$ & $46.9 \%$ & $53.1 \%$ & $0 \%$ & $0 \%$ & $0 \%$ & 4.47 & 0.507 \\
\hline $\begin{array}{l}\text { Contributes to understanding of the need for } \\
\text { collaboration in the organisation. }\end{array}$ & $40.6 \%$ & $59.4 \%$ & $0 \%$ & $0 \%$ & $0 \%$ & 4.41 & 0.499 \\
\hline $\begin{array}{l}\text { Contributes to the ability to analyse the } \\
\text { impact of individuals' actions on the } \\
\text { operation of other business areas. }\end{array}$ & $31.3 \%$ & $59.4 \%$ & $9.4 \%$ & $0 \%$ & $0 \%$ & 4.22 & 0.608 \\
\hline Helps to understand business terminology. & $31.3 \%$ & $59.4 \%$ & $9.4 \%$ & $0 \%$ & $0 \%$ & 4.22 & 0.608 \\
\hline $\begin{array}{l}\text { The impact of ERPsim on technical } \\
\text { knowledge and skills }\end{array}$ & 5 & 4 & 3 & 2 & 1 & Mean & SD \\
\hline $\begin{array}{l}\text { Contributes to the development of the } \\
\text { technical skills necessary when using SAP } \\
\text { ERP. }\end{array}$ & $28.1 \%$ & $71.9 \%$ & $0 \%$ & $0 \%$ & $0 \%$ & 4.28 & 0.457 \\
\hline $\begin{array}{l}\text { Demonstrates the need and benefits of the } \\
\text { integration of different ERP modules. }\end{array}$ & $31.3 \%$ & $65.6 \%$ & $3.1 \%$ & $0 \%$ & $0 \%$ & 4.28 & 0.523 \\
\hline $\begin{array}{l}\text { Helps to understand the role and complexity } \\
\text { of technology within ERP solutions. }\end{array}$ & $37.5 \%$ & $59.4 \%$ & $3.1 \%$ & $0 \%$ & $0 \%$ & 4.34 & 0.545 \\
\hline
\end{tabular}

The study participants are economics and business degree students, therefore the comparison can be made to our previous work [26], where the participants of the introductory simulation were IT students. When comparing the matching statements and the gathered results connected to technical knowledge, we can see that the mean values coincide. Additionally, the mean values of the statements related to business knowledge and skills are again close together. But still, when assessing the statement connected to knowledge about the collaboration in the organisation, IT students delivered slightly higher average values. This is expected since the collaborating IT students did not have any economic background, while, on the other hand, the general digital literacy is satisfactory for using SAP ERP. Hence, the students' advanced IT skills did not cause essential differences. This confirms that an introductory workshop benefits students regardless of their previous knowledge and main study field.

Within the ERPsim Distribution business simulation, students can participate in different business roles, and, consequently, implement different transactions. Since, within the introductory session, three rounds of the simulation were played, the participants were encouraged to change roles as much as possible and implement as many transactions as possible. The goal was that the students become familiar with all of the transactions representing different business processes. With a mean of 4.25 and a standard deviation of 0.718 , the participants confirmed that they changed the business roles regularly. However, as the results in Table 6 suggest, each participant did not participated in every business function, also due to the limited number of rounds played. As depicted in the Table, the majority of students participate in the pricing domain, also in the domain of stock monitoring and marketing. On the other hand, domains like sales forecast, financial monitoring, MRP and order creation and tracking, are the domains in which they participated the least. 
Table 6. Students' active involvement in different business domains in the ERPsim business simulation introductory simulation.

\begin{tabular}{ccc}
\hline Business Domain & Yes & No \\
\hline Pricing & $71.9 \%$ & $28.1 \%$ \\
Marketing & $59.4 \%$ & $40.6 \%$ \\
Sales forecast & $37.5 \%$ & $62.5 \%$ \\
MRP & $25.0 \%$ & $75.0 \%$ \\
Order creation & $34.4 \%$ & $65.6 \%$ \\
Stock monitoring & $68.8 \%$ & $31.3 \%$ \\
Order tracking & $34.4 \%$ & $65.6 \%$ \\
Sales monitoring & $50.0 \%$ & $50.0 \%$ \\
Financial monitoring & $28.1 \%$ & $71.9 \%$ \\
Market monitoring & $40.6 \%$ & $59.4 \%$ \\
\hline
\end{tabular}

Within the ERPsim simulation, participants performed different transactions following the steps presented on the JobAid. Therefore, in the post-session questionnaire, we asked them to self-assess their knowledge of various transactions. The students assessed their knowledge using a 5-point scale, where 1 stands for very low and 5 stands for excellent. The results are presented in Table 7 . The average value of the assessed knowledge is presented for each transaction. The values are provided only for the participants who participated in a belonging business role. For example, only those that participated in the pricing business domain were considered for the Change Price transaction. As seen, students know best the transactions MRP Run, Change Price and Create Planned Independent Requirements. On the other hand, students are least familiar with some of the reporting transactions, like Summary Sales Report, Financial Statements and Price Market Report.

Table 7. Average knowledge values for the transactions used in the ERPsim introductory simulation.

\begin{tabular}{lc}
\hline Transaction & Mean \\
\hline Change Price (VK32) & \\
Marketing Expense Planning(ZASD) & \\
Create Planned Indep. Req. (MD61) & 3.00 \\
MRP Run (MD001) & 3.13 \\
Create Purchase Orders (ME59N) & 3.73 \\
Inventory Report (ZMB52) & \\
Purchase Order Tracking (ZME2N) & \\
Sales Order Report (ZVA05) & \\
Summary Sales Report (ZVC2) & \\
Financial Statements (F.01) & \\
Price Market Report (ZMARKET) & \\
\hline
\end{tabular}

After the ERPsim business simulation, the students were also asked to self-assess their knowledge in the different business domains. With an average score of 3.84 and standard deviation of 0.628 , they assessed their knowledge connected to procurement, with a score of 3.72 and a standard deviation of 0.581 , the knowledge of sales and distribution and the domain of financial accounting were assessed with an average of 3.47 and standard deviation of 0.761 , all on the scale from 1 to 5 .

\subsection{Teams' Strategies, Motivation and Students' Engagement}

In addition to the research questions covering knowledge acquisition, we also looked at how the business simulation affected the students overall motivation, strategy and communication. We asked them to assess various statements using a 5-point scale, 1 standing for strongly disagree and 5 standing for strongly agree. Table 8 presents the average values and standard deviations, together with distributions. 
Table 8. The impact of the ERPsim introductory simulation on students' motivation, teams' strategy and teams' communication.

\begin{tabular}{|c|c|c|c|c|c|c|c|}
\hline $\begin{array}{l}\text { The impact of ERPsim on students' } \\
\text { motivation }\end{array}$ & 5 & 4 & 3 & 2 & 1 & Mean & SD \\
\hline $\begin{array}{l}\text { The goal was not to win, but to obtain new } \\
\text { knowledge. }\end{array}$ & $46.9 \%$ & $31.3 \%$ & $12.5 \%$ & $9.4 \%$ & $0 \%$ & 4.16 & 0.987 \\
\hline $\begin{array}{l}\text { The main motivation was getting the best } \\
\text { possible result in comparison to other teams. }\end{array}$ & $37.5 \%$ & $40.6 \%$ & $9.4 \%$ & $12.5 \%$ & $0 \%$ & 4.03 & 0.999 \\
\hline $\begin{array}{l}\text { The team rating after each round influenced } \\
\text { the motivation of the participants in the } \\
\text { continuation. }\end{array}$ & $43.8 \%$ & $37.5 \%$ & $15.6 \%$ & $3.1 \%$ & $0 \%$ & 4.22 & 0.832 \\
\hline The impact of ERPsim on teams' strategy & 5 & 4 & 3 & 2 & 1 & Mean & SD \\
\hline $\begin{array}{l}\text { The team followed a previously defined } \\
\text { strategy. }\end{array}$ & $25.0 \%$ & $56.3 \%$ & $18.8 \%$ & $0 \%$ & $0 \%$ & 4.06 & 0.669 \\
\hline $\begin{array}{l}\text { The team strategy was adjusted within the } \\
\text { rounds. }\end{array}$ & $34.4 \%$ & $62.5 \%$ & $3.1 \%$ & $0 \%$ & $0 \%$ & 4.31 & 0.535 \\
\hline $\begin{array}{l}\text { In most cases, a change in strategy led to the } \\
\text { expected results. }\end{array}$ & $28.1 \%$ & $56.3 \%$ & $12.5 \%$ & $3.1 \%$ & $0 \%$ & 4.09 & 0.734 \\
\hline $\begin{array}{l}\text { The teams shared their experiences after each } \\
\text { round. }\end{array}$ & $21.9 \%$ & $37.5 \%$ & $25.0 \%$ & $15.6 \%$ & $0 \%$ & 3.66 & 1.004 \\
\hline Our team hid certain important information. & $28.1 \%$ & $31.3 \%$ & $25.0 \%$ & $9.4 \%$ & $6.3 \%$ & 3.66 & 1.181 \\
\hline $\begin{array}{l}\text { The exchanged information after the rounds } \\
\text { was useful, and contributed to a better result } \\
\text { in the next round. }\end{array}$ & $31.3 \%$ & $37.5 \%$ & $31.3 \%$ & $0 \%$ & $0 \%$ & 4.00 & 0.803 \\
\hline $\begin{array}{l}\text { The exchanged information after the rounds } \\
\text { influenced the next round strategy. }\end{array}$ & $28.1 \%$ & $50.0 \%$ & $21.9 \%$ & $0 \%$ & $0 \%$ & 4.06 & 0.683 \\
\hline $\begin{array}{l}\text { The impact of ERPsim on teams' } \\
\text { communication }\end{array}$ & 5 & 4 & 3 & 2 & 1 & Mean & SD \\
\hline $\begin{array}{l}\text { Communication between team members } \\
\text { was good. }\end{array}$ & $50.0 \%$ & $43.8 \%$ & $6.3 \%$ & $0 \%$ & $0 \%$ & 4.44 & 0.619 \\
\hline $\begin{array}{l}\text { The introductory simulation contributed to } \\
\text { better connection with the colleagues within } \\
\text { the group. }\end{array}$ & $50.0 \%$ & $46.9 \%$ & $3.1 \%$ & $0 \%$ & $0 \%$ & 4.47 & 0.567 \\
\hline $\begin{array}{l}\text { The introductory simulation contributed to } \\
\text { the development of social skills. }\end{array}$ & $40.6 \%$ & $56.3 \%$ & $3.1 \%$ & $0 \%$ & $0 \%$ & 4.38 & 0.554 \\
\hline
\end{tabular}

The main goal of participating students was not to win, while the implemented previous study's mean values were lower, 3.4, 4.1, and 3.7, respectively. Still, the motivation in the current study was still influenced by other teams. Overall, $43.8 \%$ of participants agreed strongly that the team rating after each round influenced their motivation in the continuation. Within our previous study [26], the motivation connected to other teams was assessed higher, which coincides with previously presented results related to the participant's goal.

With an average of 4.06 , the participants agreed that the teams followed a previously designed strategy. The strategies were also adjusted between the rounds, and, with an average of 4.09, they agreed that, in most cases, the change of strategy led to the expected results. The participants also agreed that the information that they exchanged after the simulation rounds contributed to a better result in the next round, but, as shown by the results, with an average value of 3.66 , the teams hid certain important information. This could be aligned with the high average score of the statements looking into motivation connected to other teams. According to the answers, the communication within the team 
was good, and this was confirmed with an average of 4.44. The students also agreed that simulation contributed to better connection with the colleagues within the group, and also to the development of social skills.

The second part of the presented research focuses on the effect of the introductory simulation on students' future course engagement, covered by the RQ 4 presented in Section 1 and shown in the research model in Figure 2. According to related work, gamificaton and serious games have an important impact on students' course engagement. We asked the participants to assess the statement connected to future course attendance. Overall, 18.8\% of the participants agreed strongly with the statement, $40.6 \%$ agreed with the statement, $25.0 \%$ were neutral, $9.4 \%$ disagreed, and $6.3 \%$ disagreed strongly with the statement. The results are presented in Table 9. When compared with our previous work [26], the value is in-between. The assessed values by the years were 3.2, 3.9, and 4.0, respectively. In the last year, none of the participants disagreed or disagreed strongly with the statement, which confirmed that the introductory workshop positively impacts future student engagement.

Table 9. Students' opinion on gamification and the introductory simulation, and the impact of the ERPsim introductory simulation on students' future course engagement.

\begin{tabular}{|c|c|c|c|c|c|c|c|}
\hline $\begin{array}{l}\text { Opinion on gamification and introductory } \\
\text { simulation }\end{array}$ & 5 & 4 & 3 & 2 & 1 & Mean & SD \\
\hline $\begin{array}{l}\text { Virtual learning environments should be } \\
\text { upgraded with gamification elements. }\end{array}$ & $28.1 \%$ & $46.9 \%$ & $25.0 \%$ & $0 \%$ & $0 \%$ & 4.03 & 0.740 \\
\hline $\begin{array}{l}\text { The concept of an introductory simulation } \\
\text { would be appropriate within other courses. }\end{array}$ & $46.9 \%$ & $43.8 \%$ & $9.4 \%$ & $0 \%$ & $0 \%$ & 4.38 & 0.660 \\
\hline $\begin{array}{l}\text { Courses' project tasks lack } \\
\text { gamification elements. }\end{array}$ & $21.9 \%$ & $43.8 \%$ & $31.3 \%$ & $3.1 \%$ & $0 \%$ & 3.84 & 0.808 \\
\hline $\begin{array}{l}\text { The achieved results should be the part of } \\
\text { course grade where this is possible. }\end{array}$ & $31.3 \%$ & $43.8 \%$ & $18.8 \%$ & $6.3 \%$ & $0 \%$ & 4.00 & 0.880 \\
\hline $\begin{array}{l}\text { A simulation is an appropriate approach for } \\
\text { introducing the basic functionalities of } \\
\text { SAP ERP. }\end{array}$ & $34.4 \%$ & $62.5 \%$ & $3.1 \%$ & $0 \%$ & $0 \%$ & 4.31 & 0.535 \\
\hline $\begin{array}{l}\text { A simulation is appropriate for learning basic } \\
\text { navigation and use of controls in SAP ERP. }\end{array}$ & $31.3 \%$ & $62.5 \%$ & $6.3 \%$ & $0 \%$ & $0 \%$ & 4.25 & 0.568 \\
\hline $\begin{array}{l}\text { The concept of an introductory simulation } \\
\text { would be appropriate for the next generations } \\
\text { of students. }\end{array}$ & $43.8 \%$ & $46.9 \%$ & $9.4 \%$ & $0 \%$ & $0 \%$ & 4.34 & 0.653 \\
\hline The simulation was fun. & $53.1 \%$ & $37.5 \%$ & $9.4 \%$ & $0 \%$ & $0 \%$ & 4.44 & 0.669 \\
\hline $\begin{array}{l}\text { I would suggest the participation to } \\
\text { other students. }\end{array}$ & $34.4 \%$ & $56.3 \%$ & $9.4 \%$ & $0 \%$ & $0 \%$ & 4.25 & 0.622 \\
\hline $\begin{array}{l}\text { The impact of ERPsim on students' future } \\
\text { course engagement }\end{array}$ & 5 & 4 & 3 & 2 & 1 & Mean & SD \\
\hline $\begin{array}{l}\text { The attendance of lectures will increase due to } \\
\text { the introductory simulation. }\end{array}$ & $18.8 \%$ & $40.6 \%$ & $25.0 \%$ & $9.4 \%$ & $6.3 \%$ & 3.56 & 1.105 \\
\hline
\end{tabular}

Table 9 also presents the average value of the assessment for statements connected to students' opinions on gamification and the implemented introductory simulation. The participants would suggest participation to other students. This statement was assessed with a high average value of 4.25 . The students also agreed that the simulation was fun, and that the concept of the introductory simulation would be appropriate for the next generations of students. With an average value of 4.38 they agreed that the concept of an introductory simulation would also be appropriate within other courses, and, with the average of 4.31, that a simulation is an appropriate approach for introducing the basic functionalities of SAP ERP. In comparison, within our previous research [26], the students 
assessed the statement with 4.6, 4.6, and 4.4 within the three years, while none of the participants disagreed or strongly disagreed with the statement. This confirms that the business simulation used as an introduction to the course is a suitable approach, resulting in the desired knowledge and skills.

\section{Limitations}

The results of the presented study can be affected by various factors. The limitations and potential threats to validity are presented hereinafter. The research was performed using an ERPsim business simulation based on SAP ERP, using the traditional SAP GUI. Therefore, the change of interface or simulation could affect the results. The results were also impacted by the participants' backgrounds. In the research, we included business and economic professional degree students. The results could also be biased due to the participants' subjectivity, since the questionnaires were based on self-assessment statements. However, the subjectivity was reduced by ensuring anonymity. The participants used only an ERPsim user name, which was not connected to students' real identities.

\section{Conclusions}

If we want to prepare our students for the competitive business environments successfully, following the digitisation trends is crucial. This can be facilitated with the implementation of innovative teaching approaches into the existing learning curriculum supporting sustainable study programs-for example, the use of serious games, specifically business simulations. A well known and widely used representative is the ERPsim business simulation, aimed for teaching ERP concepts. The simulation is focused on easing the understanding of complex and challenging thematic connected to ERP systems. Within the presented study, we used the ERPsim business simulation as the introduction to the course, while the continuation of the course was done using traditional teaching approaches. Using a simulation only in the introduction allows a fast adaptation since only a limited number of hours are intended for the implementation, resulting only in minor changes and limited resources to verify the approach appropriateness.

Based on the research directions, we implemented an introductory simulation session in the business and economics higher education study programme. We designed a survey wherein we performed the pre- and post-questionnaires in order to gather the data needed for answering the defined research questions. Within the research, we focused on four research questions. Research questions RQ 1, RQ 2 in RQ 3 focused on knowledge acquisition, while research question $\mathrm{RQ} 4$ focused on future student course engagement. Research question RQ 1 investigated whether there was a significant difference in the students' business process knowledge before and after the ERPsim introductory simulation, RQ 2 looked to see if there was a significant difference in the students' technical knowledge for SAP ERP before and after the ERPsim introductory simulation. RQ 3 researched whether there was a significant difference in the students' ERP transaction knowledge before and after the ERPsim introductory simulation. Based on the gathered data, all three hypotheses derived from the research questions were confirmed, confirming a significant knowledge increase in the business process knowledge domain, technical knowledge domain for SAP ERP and ERP transaction knowledge domain.

On the other hand, the research question RQ 4 looked at whether the participation in the introductory simulation affected the students' intent for future course engagement. The participants assessed the statement with an average of 3.56 and a standard deviation of 1.105. Overall, $59.4 \%$ of students agreed, or agreed strongly, and only $15.7 \%$ disagreed, or strongly disagreed, with the statement that they will attend the lectures more often due to the introductory simulation. Therefore, the gathered data confirmed the research question.

The students were also asked to assessed some additional statements about teams' strategies and their motivation. It was observed that the participants' main goal was not to win in the simulation, but to gain new knowledge. However, their motivation was still connected strongly to the other teams. The teams followed the predefined strategies and assessed communication within their team as good. Participants also agreed that the 
introductory simulation is an appropriate approach for introducing the basic functionalities of SAP ERP, and also for learning the basic navigation and use of controls in SAP ERP. They liked the introductory workshop, and would suggest the participation to other, especially to the next generation, students. Based on the results, we can conclude that the ERPsim introductory simulation improved the gained knowledge significantly and undoubtedly has a positive impact on student motivation and their future course engagement. Therefore, the use of ERPsim as an introduction into the course is advisable, since it could result in many meaningful and useful effects.

Gathered results unite with the results of our previous three-year research. Whether the statements assessed the knowledge or skills or future course engagement, the students confirmed the positive effects of the introductory simulation. Therefore, the positive impact was confirmed regardless of participants prior knowledge and irrespective of their study domain.

Since the use of business simulations in higher education is an evolving topic, we will continue and research the domain further. As future work, we plan to repeat the survey and the introductory simulation on the next generation of students enrolled in business and economic professional higher education programmes. Additionally, we are also working on developing an objective instrument aimed at measuring students' knowledge acquisition.

Author Contributions: Conceptualization, T.B. and M.H.; formal analysis, T.B.; investigation, T.B. and M.H.; methodology, T.B. and M.H.; supervision, M.H.; visualization, T.B.; writing-original draft, T.B.; and writing-review and editing, T.B. and M.H. All authors have read and agreed to the published version of the manuscript.

Funding: This research received no external funding.

Institutional Review Board Statement: Not applicable.

Informed Consent Statement: Participation was optional and anonymous.

Data Availability Statement: Data can be obtained on request from the corresponding author.

Acknowledgments: The authors acknowledge financial support from the Slovenian Research Agency (Research Core Funding No. P2-0057).

Conflicts of Interest: The authors declare no conflict of interest.

\section{References}

1. Schmidt, J.T.; Tang, M. Digitalization in Education: Challenges, Trends and Transformative Potential. In Führen und Managen in der digitalen Transformation: Trends, Best Practices und Herausforderungen; Harwardt, M., Niermann, P.F.J., Schmutte, A.M., Steuernagel, A., Eds.; Springer Fachmedien Wiesbaden: Wiesbaden, Germany, 2020; pp. 287-312.

2. Zhonggen, Y. A Meta-Analysis of Use of Serious Games in Education over a Decade. Int. J. Comput. Games Technol. 2019, 2019, 4797032. [CrossRef]

3. Costa, C.; Aparicio, M.; Raposo, J. Determinants of the management learning performance in ERP context. Heliyon 2020, 6, e03689. [CrossRef]

4. Lovin, D.; Raducan, M.; Capatina, A.; Cristache, N. Sustainable Knowledge Transfer from Business Simulations to Working Environments: Correlational vs. Configurational Approach. Sustainability 2021, 13, 2154. [CrossRef]

5. Léger, P.-M.; Robert, J.; Babin, G.; Pellerin, R.; Wagner, B. ERPsim. 2007. Available online: https:/ / erpsim.hec.ca/ (accessed on 14 November 2021).

6. Nisula, K.; Pekkola, S. How to move away from the silos of business management education? J. Educ. Bus. 2018, 93, 97-111. [CrossRef]

7. Nazry, N.N.M.; Romano, D.M. Mood and learning in navigation-based serious games. Comput. Hum. Behav. 2017, 73, 596-604. [CrossRef]

8. López, F.R.; Arias-Oliva, M.; Pelegrín-Borondo, J.; Marín-Vinuesa, L.M. Serious games in management education: An acceptance analysis. Int. J. Manag. Educ. 2021, 19, 100517. [CrossRef]

9. Boyle, E.; Connolly, T.M.; Hainey, T. The role of psychology in understanding the impact of computer games. Entertain. Comput. 2011, 2, 69-74. [CrossRef]

10. Deterding, S.; Dixon, D.; Khaled, R.; Nacke, L. From Game Design Elements to Gamefulness: Defining Gamification. In Proceedings of the 15th International Academic MindTrek Conference: Envisioning Future Media Environments, Tampere, Finland, 28-30 September 2011; Volume 11, pp. 9-15. 
11. Krath, J.; Schürmann, L.; von Korflesch, H.F. Revealing the theoretical basis of gamification: A systematic review and analysis of theory in research on gamification, serious games and game-based learning. Comput. Hum. Behav. 2021, 125, 106963. [CrossRef]

12. Alsawaier, R. The Effect of Gamification on Motivation and Engagement. Int. J. Inf. Learn. Technol. 2017, 35, 56-79. [CrossRef]

13. Connolly, T.M.; Boyle, E.A.; MacArthur, E.; Hainey, T.; Boyle, J.M. A systematic literature review of empirical evidence on computer games and serious games. Comput. Educ. 2012, 59, 661-686. [CrossRef]

14. Bellotti, F.; Berta, R.; De Gloria, A. Designing Effective Serious Games: Opportunities and Challenges for Research. Int. J. Emerg. Technol. Learn. 2010, 5, 22-35. [CrossRef]

15. Qian, M.; Clark, K.R. Game-based Learning and 21st century skills: A review of recent research. Comput. Hum. Behav. 2016, 63, 50-58. [CrossRef]

16. Behnamnia, N.; Kamsin, A.; Ismail, M.A.B. The landscape of research on the use of digital game-based learning apps to nurture creativity among young children: A review. Think. Ski. Creat. 2020, 37, 100666. [CrossRef]

17. Vlachopoulos, D.; Makri, A. The effect of games and simulations on higher education: A systematic literature review. Int. J. Educ. Technol. High. Educ. 2017, 14, 1-33. [CrossRef]

18. Lamb, R.; Annetta, L.; Firestone, J. A meta-analysis with examination of moderators of student cognition, affect, and learning outcomes while using serious educational games, serious games, and simulations. Comput. Hum. Behav. 2017, 80, 158-167. [CrossRef]

19. Liberona, D.; Ahn, S.; Lohiniva, M.; Garate, P.; Rojas, C. Serious Games Usage in Higher Education, Experiences and Guidelines. In Learning Technology for Education Challenges; Uden, L., Liberona, D., Eds.; Springer International Publishing: Cham, Switzerland, 2021; pp. 138-150.

20. Juan, A.; Loch, B.; Daradoumis, T.; Ventura, S. Games and simulation in higher education. Int. J. Educ. Technol. High. Educ. 2017, 14. [CrossRef]

21. Campillo-Ferrer, J.M.; Miralles-Martínez, P.; Sánchez-Ibáñez, R. Gamification in Higher Education: Impact on Student Motivation and the Acquisition of Social and Civic Key Competencies. Sustainability 2020, 12, 4822. [CrossRef]

22. Buil, I.; Catalán, S.; Martínez, E. Encouraging intrinsic motivation in management training: The use of business simulation games. Int. J. Manag. Educ. 2019, 17, 162-171. [CrossRef]

23. Calabor, M.S.; Mora, A.; Moya, S. The future of 'serious games' in accounting education: A Delphi study. J. Account. Educ. 2019, 46, 43-52. [CrossRef]

24. Bellotti, F.; Berta, R.; De Gloria, A.; Lavagnino, E.; Dagnino, F.; Ott, M.; Romero, M.; Usart, M.; Mayer, I. Designing a Course for Stimulating Entrepreneurship in Higher Education through Serious Games. Procedia Comput. Sci. 2012, 15, 174-186. [CrossRef]

25. Boyle, E.A.; Hainey, T.; Connolly, T.M.; Gray, G.; Earp, J.; Ott, M.; Lim, T.; Ninaus, M.; Ribeiro, C.; Pereira, J. An update to the systematic literature review of empirical evidence of the impacts and outcomes of computer games and serious games. Comput. Educ. 2016, 94, 178-192. [CrossRef]

26. Beranič, T.; Heričko, M. Introducing ERP Concepts to IT Students Using an Experiential Learning Approach with an Emphasis on Reflection. Sustainability 2019, 11, 4992. [CrossRef]

27. Djaouti, D.; Alvarez, J.; Jessel, J.P.; Rampnoux, O. Origins of Serious Games; Springer: London, UK, 2011 ; pp. 25-43.

28. Abt, C. Serious Games; Viking Compass Book; Viking Press: New York, NY, USA, 1970.

29. De Gloria, A.; Bellotti, F.; Berta, R. Serious Games for education and training. Int. J. Serious Games 2014, 1, 1-15. [CrossRef]

30. Sanmugam, M.; Mohamed, H.; Abdullah, Z.; Zaid, N.; Aris, B. Gamification and Serious Games: The enigma and the use in Education. In Proceedings of the ISQAE 2014 3rd International Seminar on Quality and Affordable Education, Kuala Lumpur Malaysia, 25-28 November 2014.

31. Costa, C.J.; Aparicio, M.; Aparicio, S.; Aparicio, J.T. Gamification Usage Ecology; Association for Computing Machinery: New York, NY, USA, 2017.

32. Pasin, F.; Giroux, H. The impact of a simulation game on operations management education. Comput. Educ. 2011, 57, 1240-1254 [CrossRef]

33. Lin, Y.L.; Tu, Y.Z. The values of college students in business simulation game: A means-end chain approach. Comput. Educ. 2012, 58, 1160-1170. [CrossRef]

34. Greco, M.; Baldissin, N.; Nonino, F. An Exploratory Taxonomy of Business Games. Simul. Gaming 2013, 44, 645-682. [CrossRef]

35. Ferreira, C.P.; González-González, C.S.; Adamatti, D.F. Business Simulation Games Analysis Supported by Human-Computer Interfaces: A Systematic Review. Sensors 2021, 21, 4810. [CrossRef]

36. Léger, P.M. Using a Simulation Game Approach to Teach ERP Concepts. J. Inf. Syst. Educ. 2006, 17, $441-447$.

37. Léger, P.M.; Charland, P.; Feldstein, H.; Robert, J.; Babin, G.; Lyle, D. Business Simulation Training in Information Technology Education: Guidelines for New Approaches in IT Training. J. Inf. Technol. Educ. Res. 2011, 10, 39-53. [CrossRef]

38. Paulet, G.; Dick, G. ERPsim Games in Management Higher Education. Developments in Business Simulation and Experiential Learning: Proceedings of the Annual ABSEL Conference. 2019, Volume 46. Available online: https: / / absel-ojs-ttu.tdl.org/absel/ index.php/absel/issue/view/80 (accessed on 14 November 2021).

39. Chen, L.; Keys, A.C.; Gaber, D. How Does ERPsim Influence Students' Perceived Learning Outcomes in an Information Systems Course? An Empirical Study. J. Inf. Syst. Educ. 2015, 26, 135-146.

40. Darban, M.; Kwak, D.H.A.; Deng, S.L.; Srite, M.; Lee, S. Antecedents and consequences of perceived knowledge update in the context of an ERP simulation game: A multi-level perspective. Comput. Educ. 2016, 103, 87-98. [CrossRef] 
41. Seethamraju, R. Enhancing Student Learning of Enterprise Integration and Business Process Orientation through an ERP Business Simulation Game. J. Inf. Syst. Educ. 2011, 22, 19-29.

42. Geoffrey, D.; Asli, A. Innovative Use of the ERPsim Game in A Management Decision Making Class: An Empirical Study. J. Inf. Technol. Educ. Res. 2020, 19, 615-637.

43. Zhao, Y.A.; Srite, M.; Kim, S.; Lee, J. Effect of team cohesion on flow: An empirical study of team-based gamification for enterprise resource planning systems in online classes. Decis. Sci. J. Innov. Educ. 2021, 19, 173-184. [CrossRef]

44. Léger, P.M.; Robert, J.; Babin, G.; Lyle, D.; Cronan, P.; Charland, P. ERP Simulation Game: A Distribution Game to Teach the Value of Integrated Systems. Developments in Business Simulation and Experiential Learning. 2010; Volume 37. Available online: https://absel-ojs-ttu.tdl.org/absel/index.php/absel/article/view/328 (accessed on 14 November 2021).

45. ERPsim Lab, ERP Simulation Game, Distribution. 2021. Available online: https://erpsim.hec.ca/learning (accessed on 14 November 2021).

46. Heričko, M.; Kerman, K.; Beranič, T. Avoiding the Risks of Overgamification in Education-A Case of ERPSim. In Learning Technology for Education Challenges; Uden, L., Liberona, D., Eds.; Springer International Publishing: Cham, Switzerland, 2021; pp. 124-137.

47. Neuman, W.L. Social Research Methods: Qualitative and Quantitative Approaches, 6th ed.; Pearson International Edition; Pearson: London, UK, 2005.

48. Cronan, T.P.; Léger, P.M.; Robert, J.; Babin, G.; Charland, P. Comparing Objective Measures and Perceptions of Cognitive Learning in an ERP Simulation Game: A Research Note. Simul. Gaming 2012, 43, 461-480. [CrossRef]

49. IBM Corp. IBM SPSS Statistics for Windows; v. 27.0; IBM: Armonk, NY, USA, 2021. 